\title{
Dominika NAROŻNA
}

Uniwersytet im. Adama Mickiewicza w Poznaniu

\section{Własność intelektualna w kontekście funkcjonowania uczelni wyższej w Polsce (część 1) ${ }^{1}$}

W łasność intelektualna to rozmaite rezultaty umysłowej pracy człowieka. Ma ona charakter niematerialny. Jej odbiór ma wymiar rozumowy. Z tego względu należy odróżnić ją od tego, co jest tylko jej nośnikiem (substratem). Rzecz (dobro materialne) i przez nią ucieleśniona własność intelektualna (dobro niematerialne) to dwa różne przedmioty ochrony prawnej. Ten drugi podlega reżimowi zwanemu ,prawem własności intelektualnej", w ramach którego podstawowymi ${ }^{2}$ aktami normatywnymi są dwie ustawy ${ }^{3}$ : z dnia 4 lutego 1994 r. o prawie autorskim $i$ prawach pokrewnych (u.p.a.p.p.) ${ }^{4}$ oraz z dnia 30 czerwca 2000 r.

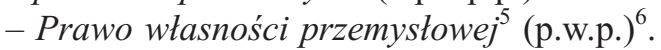

1 Przygotowany artykuł naukowy stanowi fragmenty rozprawy, którą autorka w imieniu grupy (w skład której weszli: L. Barteczka, S. W. Kuhnert, Z. Łapiński, I. Mróz, D. Narożna, F. Perucki) stworzyła na zaliczenie przedmiotu „Otoczenie prawne szkoły wyższej” w ramach uczestniczenia w studiach podyplomowych MBA „Zarządzanie uczelnią wyższą”.

2 Inne przepisy odnoszące się do obszaru tematycznego własności intelektualnej zawarte są m.in. w: ustawie z dnia 27 lipca 2001 r. o ochronie baz danych, Dz. U. $\mathrm{Nr}$ 128, poz. 1402 z późn. zm. (u.o.b.o.); ustawie z dnia 26 czerwca 1974 r. - Kodeks pracy (tekst jednolity), Dz. U. 1998, Nr 21, poz. 94 z późn. zm. (k.p.); ustawie z dnia 26 czerwca 2003 r. o ochronie prawnej odmian roślin, Dz. U. Nr 137, poz. 1300 z późn. zm. (u.o.p.r.z.); ustawie z dnia 5 sierpnia 2010 r. o ochronie informacji niejawnych, Dz. U. Nr 182, poz. 1228 (u.o.i.n.); ustawie z dnia 16 kwietnia 1993 r. o zwalczaniu nieuczciwej konkurencji (tekst jednolity), Dz. U. 2003, Nr 153, poz. 1503 z późn. zm. (u.z.n.k.); ustawie z dnia 23 kwietnia 1964 r. - Kodeks cywilny, Dz. U. Nr 16, poz. 93 z późn. zm. (k.c.).

3 W tym artykule naukowym jego autorka odwoła się tylko do pierwszego z wyżej wymienionych aktów normatywnych.

4 Dz. U. 2006, Nr 90, poz. 631 z późn. zm.

5 Prawo własności intelektualnej reguluje stosunki w zakresie wynalazków (art. 24-93 p.w.p.); wzorów przemysłowych (art. 102-119 p.w.p.); znaków towarowych (art. 120-173 p.w.p.); oznaczeń geograficznych (art. 174-195 p.w.p.); topografii układów scalonych (art. 196-221 p.w.p.), wzorów użytkowych (art. 94-101 
Prawo własności intelektualnej ma charakter terytorialny i wiąże każdego bez względu na jakiekolwiek związki z uprawnionymi. Wypełniając funkcje: własnościową, monopolizującą i wynagradzającą „stara się ważyć interesy uprawnionych z interesami pozostałych członków społeczeństwa"7 . Na uczelniach wyższych w Polsce dostrzega się ten zespół norm prawnych, choć często bagatelizuje się jego znaczenie.

\section{Przedmiot prawa autorskiego}

Praca naukowca na uczelni sprowadza się przede wszystkim do tworzenia przedmiotów prawa autorskiego, czyli utworów ${ }^{8}$. W myśl art. 1 u.p.a.p.p. są nimi wszelkie przejawy ,działalności twórczej o indywidualnym charakterze" ustalone „w jakiejkolwiek postaci niezależnie od wartości, przeznaczenia i sposobu wyrażenia"9. Zatem nie ma znaczenia, czy dana dysertacja uzyskała pozytywną czy negatywną recenzję lub czy pisana była z myślą o publikacji, czy też „do szuflady” albo czy została odczytana czy przedstawiona drukiem. Jest ona chroniona, o ile nosi cechę niepowtarzalności ${ }^{10}$. Co więcej, utwór podlega ochronie od chwili ustalenia, niezależnie od spełnienia jakichkolwiek formalności, choćby miał postać niedokończoną (art. 1 ust. 3 u.p.a.p.p.). Taka definicja może być dla twórcy kłopotliwa. Wprawdzie odciąża go od dokonywa-

p.w.p.). Zawiera również zasady, na jakich przedsiębiorcy mogą przyjmować projekty racjonalizatorskie i wynagradzać ich twórców oraz zadania i organizację Urzędu Patentowego Rzeczypospolitej Polskiej (art. 1 ust. 1 p.w.p.).

6 Dz. U. 2003, Nr 119, poz. 117 z późn. zm.

7 T. Sieniow, W. Włodarczyk, Własność intelektualna $w$ społeczeństwie informacyjnym, Warszawa 2009, s. 8.

8 Por. Zarys prawa własności intelektualnej, red. M. Kępiński, Warszawa 2010.

9 W art. 1 ust. 2 u.p.a.p.p. nie wymieniono wszystkich rodzajów utworów (katalog otwarty). Jednak ,racjonalny ustawodawca” w innych przepisach tego aktu normatywnego wymienia, co nim nie jest (odkrycia, idee, procedury, metody i zasady działania, koncepcje matematyczne, akty normatywne lub ich urzędowe projekty, opublikowane opisy patentowe lub ochronne, proste informacje prasowe, metody pracy, pomysły $\mathrm{i}$ tematy badawcze oraz teorie $\mathrm{i}$ fakty naukowe, wynalazki i wzory użytkowe, nowe odmiany roślin i zwierząt).

10 Zadaniem Sądu Najwyższego (SN) o oryginalności przesądza już sam wybór, segregacja czy określony sposób przedstawienia czegoś. Stąd też nowość nie jest przesłanką uznania danego dzieła za utwór. Zob. Wyrok SN z 25 stycznia 2006 r., I CK 281/05, OSNC 2006, nr 1, poz. 186. 
nia jakichkolwiek formalności w celu uzyskania ochrony, jednak zwiększa ryzyko wykazania w sytuacjach spornych, że jest on podmiotem prawa autorskiego.

Pracownik naukowy przy tworzeniu utworu winien mieć na uwadze: „czy”, „skąd” i „w jakim zakresie” czerpie wiedzę. Jeśli jego twórczość umysłowa w swojej zewnętrznej formie wykazuje cechy odróżniające go od innych dzieł, to można mówić o utworze samoistnym ${ }^{11}$ - niezależnym od innego podmiotu prawa autorskiego. Dla stwierdzenia tego faktu przydatna jest koncepcja tzw. statystycznej jednorazowości. Jej wykorzystanie sprowadza się do zbadania, czy takie samo lub podobne dzieło powstało już wcześniej, a także - czy jest statystycznie prawdopodobne sporządzenie w przyszłości takiego samego dzieła przez inną osobę. W przypadku uzyskania odpowiedzi przeczącej, należy uznać, iż mamy do czynienia $z$ utworem samoistnym ${ }^{12}$. Do tej kategorii zalicza się także utwory inspirowane, czyli takie, które mają cechy samodzielnej twórczości, „chociaż podnietę dał utwór cudzy”.13. Ważną kwestią, z punktu widzenia pracy naukowej, jest przyzwolenie ustawodawcy na przytaczanie „,W utworach stanowiących samodzielną całość urywków rozpowszechnionych utworów lub drobnych utworów w całości w zakresie uzasadnionym wyjaśnieniem, analizą krytyczną, nauczaniem lub prawami gatunku twórczości" (art. 29 ust. 1 u.p.a.p.p.). Należy jednak przy tym pamiętać, by cytat był rozpoznawalny (wymienienie twórcy i źródła stanowi warunek sine qua non skorzystania z prawa cytatu) oraz stanowił podrzędną rolę do całości utworu ${ }^{14}$.

Każdy naukowiec, popełniając jakąkolwiek publikację, powinien mieć na względzie treść art. 2 u.p.a.p.p., gdzie mowa jest o opracowaniu, którego przejawem jest m.in. tłumaczenie, przeróbka, adaptacja. Zwrócenie uwagi na tego typu zagadnienie ma związek $\mathrm{z}$ powstaniem prawa zależnego ${ }^{15}$.

11 Wyrok SN z 31 marca 1938 r., C II 2531/37, OSNC 1939, nr 2, poz. 61.

12 M. Brzozowska, Prawo autorskie w administracji publicznej, Wrocław 2010, s. 27.

13 Ibidem, s. 28.

14 Warto w tym momencie dodać, iż można rozpowszechniać utwór już rozpowszechniony, czyli taki, który za zezwoleniem twórcy został w jakikolwiek sposób udostępniony publicznie (art. 6 u.p.a.p.p.).

15 Zadaniem SN: ,prawo autorskie zależne powstać może wówczas, gdy istnieje uprzednio - i równolegle - autorskie prawo «pierwotne» do utworu, którego twórczego opracowania dokonała osoba powołująca się na przysługujące jej prawo zależne”. Zob. Wyrok SN z 13 stycznia 2006 r., III CSK 40/05, Lex nr 176385. 
Jego konsekwencją jest wyrażenie zgody twórcy utworu pierwotnego na rozporządzanie i korzystanie z jego ,przejawu działalności twórczej o indywidualnym charakterze". Zatem książkę obcojęzyczną można przetłumaczyć tylko na własny użytek (np. w ramach ćwiczeń językowych), jednak nie ma się prawa do rozporządzania tym utworem zależnym ${ }^{16}$ (zwłaszcza w celach zarobkowych) bez uzyskania zgody autora dzieła samoistnego.

\section{Podmioty prawa autorskiego}

Naukowiec $\mathrm{z}$ założenia jest twórcą ${ }^{17}$. Z tego tytułu przysługują mu autorskie prawa osobiste, które chronią jego więź z utworem w szczególności w zakresie autorstwa, oznaczenia dzieła swoim nazwiskiem lub pseudonimem albo udostępnienie go anonimowo, nienaruszalności jego formy i treści, jego rzetelnego wykonania, decydowania o jego pierwszym udostępnieniu publiczności, nadzorze nad sposobem korzystania z utworu (art. 16 u.p.a.p.p.) oraz autorskie prawa majątkowe w postaci prawa do: korzystania z dzieła, rozporządzania nim na wszystkich polach eksploatacji, do wynagrodzenia za korzystanie z niego (art. 17 u.p.a.p.p.). O ile te pierwsze są nieograniczone w czasie oraz nie podlegają zrzeczeniu się lub zbyciu, to te drugie są zbywalne i trwają 70 lat liczonych „w pełnych latach następujących po roku, w którym nastąpiło zdarzenie, od którego zaczyna się bieg terminów określonych w art. 36 i $37^{\prime \prime} 18$ u.p.a.p.p.

Zgodnie $\mathrm{z}$ generalną regułą wyrażona w art. 8 u.p.a.p.p. autorskie prawo majątkowe do prac licencjackich, magisterskich, doktorskich ${ }^{19}$ i habilitacyjnych przysługuje generalnie ich twórcom. W doktrynie pojawiają się jednak głosy, że współautorami prac dyplomowych studentów

16 Prawo własności intelektualnej, red. J. Sieńczyło-Chlabicz, Warszawa 2009, s. $86-87$.

17 W świetle art. 8 u.p.a.p.p. jest nim „osoba, której nazwisko w tym charakterze uwidoczniono na egzemplarzach utworu lub której autorstwo podano do publicznej wiadomości w jakikolwiek inny sposób w związku z rozpowszechnianiem utworu".

18 Por. Kiedy osobiste, kiedy majatkowe?, „Rzeczpospolita” (dodatek specjalny), 20 czerwca 2011, nr 142, s. 4.

19 J. Sobczak, Wykłady z ochrony własności intelektualnej dla doktorantów w roku akademickim 2006/2007 przeprowadzone na Wydziale Nauk Społecznych Uniwersytetu im. Adama Mickiewicza w Poznaniu. 
na gruncie art. 9 u.p.a.p.p. są promotorzy tych rozpraw. Nie do końca wypada się zgodzić z tym stanowiskiem, gdyż sam fakt umieszczenia nazwiska na egzemplarzu dzieła nie jest równoznaczny z przypisaniem komuś miana podmiotu prawa autorskiego. W tym przypadku decydujące znaczenie będzie miał bowiem wkład twórczy przy realizacji danej rozprawy, który może ustalać sąd.

\section{Umowa o pracę}

Podstawową regulacją, na mocy której pracodawca staje się podmiotem prawa autorskiego pracobiorcy, jest art. 12 u.p.a.p.p. ${ }^{20} \mathrm{Z}$ treści tego przepisu wywodzą się dwie przesłanki takiego stanu rzeczy: stworzenie utworu w wyniku wykonywania obowiązków wynikających ze stosunku pracy (przesłanka pozytywna) oraz brak odmiennych postanowień umownych między pracownikiem a pracodawcą (przesłanka negatywna). Interpretacja sformułowania ,stworzenie utworu w wyniku wykonywania obowiązków wynikających ze stosunku pracy" rodzi jednak wiele niejasności. W każdym przypadku analizy tego fragmentu przepisu należy odwołać się do dokumentów pracowniczych stanowiących podstawę nawiązania stosunku pracy i wyznaczających zakres przypisanych danemu pracownikowi obowiązków (np. umowa o pracę, regulamin pracy, układy zbiorowe). Jeśli w dokumentach źródłowych charakterystyka obowiązków pracowniczych jest na tyle ogólna, że powstają wątpliwości, czy można powiązać z nimi stworzenie utworu przez konkretnego pracownika, to należy posiłkować się kryteriami pomocniczymi. Są one przewidziane przez przepisy prawa cywilnego tj. wyznaczniki celu zawartej umowy i zgodnego zamiaru stron oraz ustalonych zwyczajów panujących w danym zakładzie pracy (art. 56 i 65 k.c. ${ }^{21}$ oraz art. 12 ust. 1 pr. u.p.a.p.p.). Jak zauważa R. Golat w razie pojawienia się niejasności, czy dany utwór został stworzony w wyniku wykonywania obowiązków

20 Regulacja „utworów pracowniczych” nie obejmuje dzieł stworzonych w oparciu o umowy cywilnoprawne (umowa o dzieło czy umowa zlecenie). W tych przypadkach - co podkreślają J. Barta i R. Markiewicz - kwestia uprawnień zamawiającego do eksploatowania utworu oceniania jest w świetle przepisów rozdziału 5 u.p.a.p.p. o nazwie „Przejście autorskich praw majątkowych”. Zob. J. Barta, R. Markiewicz, Prawo autorskie, Warszawa 2010, s. 77.

21 Ustawa z dnia 23 kwietnia 1964 r. - Kodeks cywilny, op. cit. 
pracowniczych, nie można sugerować się takimi okolicznościami jak np. miejsce i czas wykonywania pracy, czy przynależność środków technicznych przy pomocy których dany utwór powstał: „nawet jeśli twórca opracował utwór przy wykorzystaniu komputera, stanowiącego własność pracodawcy, w trakcie przebywania w zakładzie pracy w godzinach przeznaczonych regulaminowo na jej świadczenie, nie oznacza to jeszcze, że z mocy prawa doszło do nabycia autorskich praw majątkowych do takiego utworu przez zatrudniającego"22. Wyczula on także czytelnika na zagadnienie polecenia służbowego. Za słuszne uznaje twierdzenie, że jego wydanie może doprowadzić do nabycia autorskich praw majątkowych do utworu przez pracodawcę tylko wtedy, gdy stanowi to konkretyzację obowiązków pracowniczych. Konkludując swój wywód podkreśla, iż strony stosunku pracy mają dużą swobodę w regulowaniu swoich wzajemnych relacji ${ }^{23}$.

Należy podkreślić, że pracownicy chcąc pozyskać pracę mają słabszą pozycję i trudniej im wpływać na modyfikację zasady zwartej w art. 12 ust. 1 u.p.a.p.p. Pamiętać jednak należy, iż milcząca formuła umowy o pracę nie zawsze jest najlepszym rozwiązaniem dla pracobiorcy. Dobrze jest zatem na wstępie zawrzeć pewien kompromis polegający na częściowym ograniczeniu ustawowego monopolu zatrudniającego przez m.in. wskazanie, w jakim zakresie pracodawca będzie podmiotem uprawnionym do pracowniczego utworu (np. poprzez wskazanie pól eksploatacji lub czasowy bądź ilościowy zakres korzystania przez pracodawcę z pracowniczych utworów) ${ }^{24}$. Warto przy tym wspomnieć, że nabycie praw majątkowych do utworu w świetle art. 12 u.p.a.p.p. ma ograniczony charakter czasowy. Autorskie prawa majątkowe w momencie powstania przysługują pracownikowi. Dopiero, gdy pracodawca przyjmie przedmiot prawa autorskiego ${ }^{25}$, następuje ich nabycie przez twórcę. Od tego momentu ma on dwa lata na rozpoczęcie rozpowszechniania przedmiotu prawa autorskiego. Jeśli tego nie uczyni, prawa te wracają do

22 R. Golat, Prawa autorskie i prawa pokrewne, Warszawa 2010, s. 117.

23 Zob. Wyrok SN z 26 czerwca 1998 r., I PKN 196/98, OSNP APiUS 1999, nr 14, poz. 454.

24 R. Golat, Prawa autorskie i, op. cit., s. 118.

25 „Jeśli pracodawca nie zawiadomi twórcy w terminie sześciu miesięcy od dostarczenia utworu o jego nieprzyjęciu lub uzależnieniu przyjęcia od dokonania określonych zmian w wyznaczonym w tym celu odpowiednim terminie, uważa się, że utwór został przyjęty bez zastrzeżeń”. Zob. art. 13 u.p.a.p.p. ustawy z dnia 4 lutego 1994 r. o prawie autorskim i prawach pokrewnych, op. cit. 
pracobiorcy, o ile wcześniej ten drugi wyznaczył termin na piśmie na rozpoczęcie rozpowszechnia utworu, który upłynął bez powzięcia kroków przez tego pierwszego (art. 12 ust. 2 u.p.a.p.p.).

\section{Pierwszeństwo opublikowania utworu}

Treść umowy o pracę rzutuje także na problem pierwszeństwa opublikowania utworu naukowego pracownika przez instytucję naukową. Należy podkreślić, iż ma to charakter jednorazowego przywileju. Stąd w tym przypadku nie można mówić o przeniesieniu autorskich praw majątkowych, ale o szczególnym rodzaju uprawnienia licencyjnego ${ }^{26}$. Zdaniem J. Barty i R. Markiewicza reguły te, zawarte w art. 14 u.p.a.p.p., są korzystniejsze od art. 12 tego aktu normatywnego. Ograniczają bowiem uprawnienia pracodawcy do pierwszeństwa publikacji, co nie jest jednak równoznaczne $\mathrm{z}$ wyłączeniem prawa do decydowania twórcy o pierwszym udostępnieniu dzieła publiczności. Trzeba przy tym zaznaczyć, iż jednostka naukowa może skorzystać z pierwszeństwa opublikowania utworu dopiero po uzyskaniu pozytywnej decyzji twórcy dotyczącej publikacji ${ }^{27}$.

Uczelnia może korzystać jedynie z uprawnień eksploatacyjnych $\mathrm{z}$ art. 14 u.p.a.p.p. i tylko w odniesieniu do dzieł pracowników, wykonanych $\mathrm{w}$ ramach obowiązków pracowniczych. Podmiotowy zakres tego przepisu nie obejmuje studentów (w tym doktorantów). Tylko na pozór słusznym wydaje się postulat zwarcia z takimi osobami przez szkoły wyższe umowy licencyjnej lub przenoszącej prawa majątkowe ${ }^{28}$, gdyż może to budzić wątpliwość co do ważności treści umowy w świetle art. 58 k.c., kiedy jest ona zawierana przed terminem obrony dysertacji, „a jej treść stanowi o nieodpłatnym przeniesieniu wspomnianych praw

26 R. Golat, Prawa autorskie i, op. cit., s. 119-120.

27 J. Barta, R. Markiewicz, Prawo autorskie, Warszawa 2010, s. 77.

28 W rejestr umownych klauzul niedozwolonych prowadzonego przez Urząd Ochrony Konkurencji i Konsumentów (UOKiK) wpisano bowiem zapis, według którego: „Student przenosi na uczelnie autorskie prawa majątkowe do swojej pracy dyplomowej [...] przygotowanej $\mathrm{w}$ ramach studiów realizowanych na uczelni $\mathrm{X}$. Przeniesienie praw autorskich następuje nieodpłatnie na wszystkich polach eksploatacji [...]". Zob. Wyrok Sadu Ochrony Konkurencji i Konsumentów z 6 kwietnia 2006 r., XVII AmC 48/05, niepubl. 
bądź udzieleniu licencji w zbyt szerokim zakresie"29. Powołując się jednak na treść przepisu zawartego w art. 15a u.p.a.p.p., to uczelni (w rozumieniu przepisów o szkolnictwie wyższym) przysługuje pierwszeństwo w opublikowaniu pracy dyplomowej studenta, ale tylko w terminie 6 miesięcy od jej obrony. Nie jest to jednak równoznaczne ze zbyciem się przez niego autorskich praw majątkowych. Po tym okresie student ma prawo samodzielnie opublikować swoją pracę. Jeśli wykryje, że dana osoba przypisała sobie autorstwo, może dochodzić swoich praw przed sądem.

\section{Zwielokrotnianie utworów}

Jednym z najczęstszych problemów z zakresu prawa własności intelektualnej jest kwestia zwielokrotniania utworów. Jeśli wykładowca kseruje materiały dla żaków, to w świetle prawa legalne jest zwielokrotnienie tylko fragmentu utworu, koniecznego do realizacji założeń dydaktycznych, mając przy tym na względzie to, by zapoznanie się z nim nie zastępowało zaznajomienia się z całością przedmiotu prawa autorskiego (art. 27 u.p.a.p.p.). Jednak w tym przypadku nic nie stoi na przeszkodzie, by zwielokrotnione fragmenty egzemplarzy były wykorzystywane przez następne roczniki studentów. Nie ulega jednak żadnej wątpliwości, iż powielanie utworów powoduje zagrożenie majątkowych interesów podmiotów praw autorskich ${ }^{30}$ poprzez redukcję dochodów płynących z eksploatacji dziel ${ }^{31}$.

Omawiając kwestię zwielokrotniania utworów nie sposób nie odnieść się do zagadnienia własnego użytku osobistego. W treści art. 23 u.p.a.p.p. istnieje bowiem zezwolenie na nieodpłatne korzystanie z już rozpowszechnionego dzieła w tym zakresie. Definicja ta obejmuje korzystanie z pojedynczych egzemplarzy utworów także „przez krąg osób pozostających w związku osobistym, w szczególności pokrewieństwa, powino-

29 Zob. J. Barta, R. Markiewicz, Prawo autorskie, Warszawa 2010, s. 79.

30 Prawo autorskie i prawa pokrewne. Zarys wykładu, red. M. Późniak-Niedzielska, Bydgoszcz-Warszawa-Lublin 2007, s. 91-100.

31 Stąd też wydawnictwa naukowe stworzyły „Grupę Walczącą o Przestrzeganie Praw na Uczelniach". W jej skład weszły: Wydawnictwo Naukowe PWN, LexisNexis, C. H. Beck, Scholar, Wolters Kluwer, Universitas K. Łokaj. Zob. Czy można kserować ksiażki?, http:/www.mmwroclaw.pl/333402/2010/10/18/czy-mozna-kserowac-ksiazki?category=news $(23.05 .2011)$. 
wactwa lub stosunku towarzyskiego" (art. 23 ust. 2 u.p.a.p.p.). Wracając zatem do tematyki kserowania okazuje się, że jeśli student dokonuje tej czynności na własne potrzeby, a zwielokrotniony egzemplarz wykorzystuje przez siebie w celach naukowo-dydaktycznych (co najwyżej udostępnia go kolegom z roku, z którymi przyjaźni się, czy kuzynce studiującej ten sam kierunek na innym uniwersytecie) nie czerpiąc $\mathrm{z}$ tego żadnych korzyści, to ma do tego prawo.

\section{Uczelniane eventy artystyczno-kulturalne}

Należy pamiętać, iż przedsięwzięcia artystyczno-kulturalne podejmowane na uczelniach wyższych w Polsce podlegają reżimowi prawa autorskiego i praw pokrewnych. Stąd jeśli artysta-wykonawca prezentuje „na żywo" cudze utwory ${ }^{32}$, to nie tylko jemu należy się stosowne wynagrodzenie, lecz także twórcom przedmiotu prawa autorskiego (tzw. tantiemy). W pierwszym przypadku należy podpisać z podmiotem odpowiednią umowę, a w drugim - w większości przypadków przekazać określoną kwotę pieniężną do właściwej organizacji zbiorowego zarządzania prawami autorskimi, która następnie wypłaci wynagrodzenie twórcy utworu ${ }^{33}$. Dotykając tego drugiego zagadnienia pojawia się jednak pytanie, kto ma uiścić takie tantiemy? Odpowiedź reguluje treść umowy zawartej pomiędzy artystą-wykonawcą a uczelnią, w ramach której określa się, na kim spoczywa ten obowiązek. Dobrze jest także w tym przypadku ustalić, czy twórca powierzył komukolwiek zarząd prawami autorskimi, gdyż na mocy art. 105 u.p.a.p.p. istnieje domniemanie $^{34}$, że ,organizacja zbiorowego zarządzania jest uprawniona do zarządzania i ochrony w odniesieniu do pól eksploatacji objętych zbiorowym zarządzaniem oraz ma legitymację procesową w tym zakresie".

32 Mowa tu o prawie do artystycznego wykonania (będącego prawem pokrewnym), które może odbywać się na określonych polach eksploatacji, wyliczonych w art. 86 u.p.a.p.p.

33 Twórcy utworów nie mając możliwości kontroli nad bezprawnym korzystaniem z ich przejawów działalności twórczej, powierzają w zarząd swoje prawa autorskie właściwej organizacji zbiorowego zarządzania (np. stowarzyszeniu ZAIKS) poprzez podpisanie umowy. Tym samym taka organizacja reprezentuje twórcę w relacjach z podmiotami, które chcą wykorzystać jego dzieło.

34 Jednak nie można się na nie powołać w przypadku, gdy rości sobie tytuł do tego samego utworu więcej niż jedna organizacja zbiorowego zarządzania. 
Stąd też może ona zawrzeć umowę z uczelnią, która daje podstawę do inkasowania honorariów autorskich na rzecz twórców niechronionych przez tę organizację. Jednocześnie zobowiązuje się przekazania uprawnionym należnych wynagrodzeń na zasadach identycznych jak stosowanie wobec autorów, którzy powierzyli jej swoje prawa ${ }^{35}$.

\section{Zdjęcia}

Fotografie, wymienione expressis verbis w treści art. 1 ust. 2 u.p.a.p.p. jako przykładowa kategoria przedmiotów chronionych mogą w środowisku akademickim pełnić szereg funkcji: informacyjną (to ilustracje bieżących wydarzeń), badawczą (fotografie naukowe), poznawczą (fotografie reporterskie), rzemieślniczą (fotografie dokumentacyjne). Jednak brak legalnej definicji stwarza naukowcom problem w wytyczeniu granic oryginalności jako przesłanki uznania jej za przedmiot prawa autorskiego. Należy zgodzić się z R. M. Sorbańskim, który uważa, że fotografia winna być chroniona w przypadku, gdy stanowi subiektywne spojrzenie fotografa na zdjęcie. Twórczość przejawia się w świadomości wyboru momentu zrobienia zdjęcia czy punktu widzenia, kadrowania czy zabiegów zmierzających do nadania fotografii określonego charakteru ${ }^{36}$. Jeśli zatem uczelnia wynajmuje fotografa, to winna $\mathrm{z}$ nim zawrzeć umowę, w której dokładnie przedstawia warunki (zwłaszcza określa pola eksploatacji korzystania z dostarczonych utworów oraz kwestie wynagrodzenia za wykonaną pracę w ramach umowy cywilnoprawnej). Natomiast odmiennym zagadnieniem regulowanym na gruncie u.p.a.p.p. jest ochrona wizerunku ${ }^{37}$ (art. 81 u.p.a.p.p.). Generalna zasada mówi, że jego rozpowszechnianie wymaga zgody osoby na nim przedstawionej ${ }^{38}$. Nie ma to jednak zastosowania w przypadku, gdy osoba otrzymała zapłatę za pozowanie lub jest powszechnie znana lub o ile wizerunek wykorzysta-

35 M. Brzozowska, Prawo autorskie, op. cit., s. 51-52.

36 Wyrok SN z 5 lipca 2002 r., III CKN 1096/00, nr 11, poz. 150, LEX nr 81369.

37 Warto wspomnieć, że wizerunek jest na gruncie art. 23 i 24 k.c. zaliczany do kategorii „,dóbr osobistych”.

${ }^{38}$ Granice wykonywania tego prawa określa również art. 5 k.c., który dotyczy nadużycia prawa podmiotowego. Zezwolenie jest z reguły udzielane jednemu, konkretnemu podmiotowi, który w związku z tym nie może - chyba, że postanowiono inaczej - przenosić swoich uprawnień na inne osoby. Zob. Prawo autorskie i prawa pokrewne. Zarys wykładu, M. Późniak-Niedzielska, op. cit., s. 136. 
no w związku z pełnieniem przez nią funkcji publicznej (politycznej, społecznej, zawodowej), czy jednostka stanowi jedynie „fragment większej całości" (zgromadzenie, krajobraz, publiczna impreza). Zatem zasadniczo zgoda studenta, który otrzyma wynagrodzenie za umieszczenie jego postaci na ulotce uczelni; rektora uczelni wyższej na pokazanie jego wizerunku w związku z pełnioną przez niego funkcją (nie z jego sferą życia prywatnego!), czy publiczności zgromadzonej w auli uniwersyteckiej z okazji jubileuszu funkcjonowania Almae Matris umieszczonej na zdjęciu nie jest wymagana.

\section{Plagiat jako forma kradzieży intelektualnej}

Bolączką polskich uczelni wyższych, z punktu widzenia ochrony dóbr niematerialnych, wydaje się być zjawisko dokonywania kradzieży intelektualnej w postaci popełniania plagiatu, czyli ,przywłaszczenia sobie autorstwa albo wprowadzenia w błąd co do autorstwa w całości lub części cudzego utworu lub artystycznego wykonania" (art. 115 u.p.a.p.p.). Czyn ten zagrożony jest karą grzywny, ograniczenia albo pozbawienia wolności do lat trzech. Warto przy tym zaznaczyć, iż utwory weryfikowane przez dr. M. Wrońskiego ${ }^{39}$ pozwalają na konstatację, że naukowcy popełniają najczęściej częściowy plagiat prosty, przepisując fragment czyjegoś dzieła, oraz złożony, przetwarzając czyjś utwór bez wskazania - w jednym i drugim przypadku - źródła i autora przedmiotu prawa autorskiego $^{40}$. Należy w tym miejscu przytoczyć, że polskie ustawodawstwo nie zna instytucji ,autoplagiatu”. Oznacza to tyle, że każdy (w tym pracownik naukowy) możne plagiatować samego siebie. Idąc tym tokiem rozumowania dozwolone w świetle prawa jest bezpośrednie wykorzystywanie fragmentów własnych utworów w swoich nowych dziełach

39 Dr M. Wroński od kilku lat prowadzi w miesięczniku „Forum Akademickie” cykl „Z archiwum nieuczciwości naukowej”, gdzie opisuje przypadki nieuczciwości naukowej polskich uczonych.

40 W ostatnich kilku miesiącach do głośnych wydarzeń medialnych zalicza się sprawy o popełnienie plagiatu przez rektorów uczelni wyższych w Polsce. Zob. T. Wysocki, Gdyby prof. Andrzejak przeprosit, zachowałby funkcje, http://wroclaw.gazeta.pl/wroclaw/1,35771,9666800,Spotkanie_z_tropicielem_nieuczciwych_naukowcow.html (23.05.2011); P. Żytnicki, Prof. Kamela-Sowińskä i plagiat Wikipedii, http://poznan.gazeta.pl/poznan/1,36037,7711019,Prof_Kamela_Sowinska_i_plagiat_ z_Wikipedii.html (29.06.2011). 
czy tłumaczenie własnego artykułu naukowego na kilka języków obcych i publikacja ich w różnych czasopismach. Kwestią otwartą pozostaje natomiast sfera etyki zawodowej.

\section{Wizja przyszłości}

Według sondażu przeprowadzonego na zlecenie Polskiej Agencji Rozwoju Przedsiębiorczości (PARP) ranking wiedzy niechcianej w środowiskach akademickich otwiera problematyka ochrony własności intelektualnej ${ }^{41}$. Do tej pory tylko nieliczne jednostki naukowe pokusiły się na wprowadzenie regulaminu dotyczącego zasad ochrony i zarządzania dobrami niematerialnymi ${ }^{42}$. Jednak ustawodawca $\mathrm{w}$ art. $86 \mathrm{c}$ ustawy z dnia 18 marca 2011 r. o zmianie ustawy - Prawo o szkolnictwie wyższym, ustawy o stopniach i tytule naukowym oraz stopniach i tytule $w$ zakresie sztuki oraz niektórych innych ustaw ${ }^{43}$ nakłada obowiązek wprowadzenia regulaminu zarządzania prawami autorskimi i prawami pokrewnymi oraz prawami własności przemysłowej oraz zasad komercjalizacji wyników badań naukowych i prac rozwojowych. Taki dokument winien określać: prawa i obowiązki uczelni, pracowników, studentów i doktorantów w tym zakresie; zasady wynagradzania twórców; zasady i procedury komercjalizacji wyników badań naukowych, czy prac rozwojowych, a także korzystania z majątku jednostek naukowo-badawczych w tym zakresie oraz świadczenia usług naukowo-badawczych. Zatem przed szkołami wyższymi w Polsce stoi wielkie wyzwanie ${ }^{44}$.

41 Do zrobienia jest naprawde wiele - sondaże PARP nie pozostawiaja złudzeń, w: Zarzqdzanie Własnościq Intelektualnq, red. B. Węgliński, Warszawa-Józefowo 2010, s. 169.

42 Uczyniły to m.in. Politechnika Gdańska (PG) czy Uniwersytet Jagielloński (UJ).

43 Dz. U. Nr 84, poz. 455 z późn. zm.

44 Obecnie m.in. na Uniwersytecie im. Adama Mickiewicza w Poznaniu (UAM) trwają zintensyfikowane prace nad wdrożeniem regulaminu ochrony i korzystania z własności intelektualnej. Rozpoczęto je w roku akademickim 2007/2008 w ramach projektu pilotażowego Ministerstwo Nauki i Szkolnictwa Wyższego (MNiSW), następnie w 2010 r. zainaugurowano pracę nad nowym dokumentem w grupie eksperckiej, by w pierwszej połowie czerwca 2011 r. przedstawić spójny dokument przekazany do konsultacji członków Komisji Rektorskiej ds. współpracy z gospodarką na UAM. Zob. J. Wajda, Regulamin ochrony i korzystania z własności intelektualnej UAM, Wystapienie w ramach Akademii Przedsiębiorczości na Uniwersytecie im. Adama Mickiewicza w Poznaniu, Poznań 23 maja 2011 r. 


\section{Intellectual property in the context of higher education institutions operating in Poland (part 1)}

\section{Summary}

Polish higher education institutions are facing the task of managing issues of intellectual property protection. This task is imposed on them by law in Article $86 \mathrm{c}$ of the Law of March 18, 2011 on the amendment to the Law on higher education, the Act on academic degrees and titles and degrees and degrees and titles in art and some other acts. The topicality of this issue has encouraged the author of the paper to discuss copyright, plagiarism and to indicate certain manners of using academic works. 
